\title{
Odgoj i obrazovanje u Plemićkom konviktu u Zagrebu od 1852. do 1914. godine
}

\author{
Katarina Dadić*, Vlatko Smiljanić**
}

\begin{abstract}
Sažetak
Temeljem kritičke interpretacije arhivskoga gradiva, novinskih članaka i relevantne literature autori se bave djelovanjem Plemićkoga konvikta u Zagrebu. On nalazi uporište u isusovačkoj odgojno-obrazovnoj tradiciji i utjecajima povijesno-političkih okolnosti od njegove obnove sredinom 19. stoljeća do Prvoga svjetskoga rata. Rad je usredotočen na organizacijske i odgojno-obrazovne postulate djelovanja konvikta, kao i na svakidašnjicu pitomaca u zadanom razdoblju.
\end{abstract}

Ključne riječi: domska pedagogija; isusovci; Plemićki konvikt u Zagrebu; povijest odgoja

\section{Uvod}

Isusovci su na području hrvatskih zemalja tijekom ranomodernoga doba dali temelje za odgojne, obrazovne i didaktičke modele koje danas poznajemo. Arhivski izvori svjedoče nam da su već u prvoj polovici 17. stoljeća u Zagrebu uspjeli organizirati crkvu, kolegij i gimnaziju (Vanino, 1969, 231). Stoga, u ovom radu autori analizom arhivskoga gradiva, koje je sačuvano u Državnom arhivu u Zagrebu, te analizom periodike (Napredak, Narodne novine i Obzor) kao i relevantne literature, istražuju povijesni kontekst razvoja i djelovanja Plemićkoga konvikta, s osobitom pažnjom na gledišta odgoja i obrazovanja unutar njega od obnove rada 1851. do početka Prvoga svjetskoga rata 1914. godine.

Spomen o konviktu seže u početak 17. stoljeća. Rektor turočkoga kolegija Ivan Žanić, upravitelj olomoučkoga kolegija Petar Vragovićni i zagrebački gradski sudac Baltazar Vlahović organizirali su 1606. isusovačku djelatnost u Zagre-

* Doc. dr. sc. Katarina Dadić, Fakultet hrvatskih studija Sveučilišta u Zagrebu, Odsjek za odgojno-obrazovne znanosti. Adresa: Borongajska cesta 83d, 10000 Zagreb, Hrvatska. ORCID iD: https://orcid.org/0000-0002-3371-6297 E-adresa:kdadic@hrstud.hr

** Vlatko Smiljanić, mag. educ. hist., Fakultet hrvatskih studija Sveučilišta u Zagrebu. Adresa: Borongajska cesta 83d, 10000 Zagreb, Hrvatska. ORCID iD: https://orcid.org/0000-0001-9835-0591. E-adresa:vsmiljanic@hrstud.hr 
bu. Četiri godine kasnije, štajerski vojvoda Ferdinand II. darovao je isusovačkomu kolegiju zgradu »vojničke opskrbne oblasti« (Hervoić, 1874, 1) (današnja zgrada Gimnazije Tituš Brezovački), aurum coreale te 2.000 forinti kao pomoć za izgradnju crkve. Austrijski je dvor nastavio darivati zagrebačke isusovce, a među njima su se istaknuli Ferdinand III., Leopold Wilhelm te Leopold I., koji im je osim posjeda Paukovec darovao »zaštitu staležah, prelatah i velmožah « (Hervoić, 1874, 1), čime su isusovci postali prihvaćeni među austrijskim i hrvatskim velikodostojnicima. Od darovnice oporučne zaklade Nikole Frankopana 23. ožujka 1627. u iznosu od 10.000 forinti te poklanjanjem kuće i vrta Ivana Draškovića 18. prosinca 1627. možemo govoriti o početku rada konvikta.

Prve podatke »o uzgoju mladeži kao cilju i svrhi zagrebačkoga kolegija « nalazimo u izvorima koji prvu »uzgojnu« zakladu datiraju u 1642. godinu, čiji je predstavnik bio »pater Ignac i grof Thonhausen«. Tada je bilo organizirano podučavanje mladeži »na gimnaziji i akademiji«, o čemu je pisao i Miroslav Vanino (1969, 225-260). Međutim, znamo kada su i tko je osnivao zaklade, koje su osiguravale prijeko potrebne financije za odgojno-obrazovnu djelatnost. Tako, nakon Frankopana imamo Smolčićevu zakladu (1643.), Škrlecovu (1659.), Zakmardijevu (1667.), Ručićevu (1667.), Abantyjevu (1671.), Uzolićevu (1692.), Plemićevu (1716.), Patalijevu (1734.) i Prünerovu (1710.). Prije svega, plemstvu, koje je utemeljilo zaklade, bilo je izuzetno važno obrazovanje mladeži i tu su nadu za odgoj i obrazovanje zasigurno prepustili isusovcima (Hervoić, 1874, 1-4).

Drugo, očito je da je pristupanje mladeži bilo dobro jer su zaklade bile osnivane vrlo brzo nakon uspostave rada konvikta. Iako su isusovci kao crkveni red bili podložni političkim mijenama, njihove ideje uspjele su nadići povijesnu zbilju. Unatoč ukidanju reda, vlasti su bile uporne održati konvikt i njegovu djelatnost, a tomu svjedoči odluka kraljevskoga namjesništva br. 4515 iz 20. rujna 1776., prema kojoj »ravnateljstvo sjemeništah vieštin sviećenikom razpuštenih kollegijah povieriti« (Hervoić, 1874, 5). Kao takav konvikt je opstajao do 1784., kada je ukinut, a sav imetak predan je u državnu blagajnu i opću stipendijsku zakladu. To je, dakle, bio prvi korak prije potpunoga podržavljenja konvikta. Unatoč tomu, uslijedila su burna vremena (austrijski bankrot 1814. i ratovi s Napoleonom) osnivanja i ponovnih ukidanja konvikta u kontekstu političkih promjena. Ipak, razlog zatvaranja nije bio toliko financijski koliko obrambeno-sigurnosni. Konvikt je ponovno otvoren 1820. godine. Ratno stanje ostavilo je i demografske posljedice. Konvikt je tada bilježio samo 28 pitomaca, što je za $38 \%$ manje pitomaca od statistike iz 18. stoljeća. Godine 1848. tzv. proljeće naroda bilo je uzrokom obustave primanja pitomaca, no ravnateljstvo je i u tim vremenima uspjelo opstati. Zgradu je ponovno zauzela vojska i to carsko-kraljevska pješačka pukovnija Franje Karla te žandarmerija. Konačno, od 1851. konvikt je ponovno bio otvoren. ${ }^{1}$

1 HR-HDA-516. Kraljevski plemićki konvikt. Povijest i Sadržaj jedinice. Usp. Hervoić, 1874, 8-10; Laszowski, 1939. 


\section{Upravna povijest konvikta izmedu politike i realnosti}

Nakon što su sredinom 1851. iz zgrade konvikta iselili vojnici i novoustrojeno oružništvo, konvikt je započeo s ponovnim radom na isusovačkim tradicijama. Dokaz tomu je što su iz navedenoga razdoblja sačuvani dokumenti za rad konvikta. Posebno je važan statut, koji je donesen još 1798., a preveden na hrvatski jezik tijekom druge polovice 19. stoljeća, te svjedoči njegovu važnost i kontinuitet primjene. Ravnatelja konvikta imenovao je Franjo Josip I. Njegov zamjenik bio je glavni ekonom konvikta. ${ }^{2}$ Tri prefekta, koji su živjeli i radili u konviktu, vodili su tri kamerade, družbe pitomaca. Svaka je grupa imala repetitora, koji je bio ili filozof ili pravnik, a njegov zadatak bio je nadgledanje učenja pitomaca (usp. Vrbanus, s. a.). Od 1852. ravnatelj konvikta bio je zagrebački kanonik Josip Clemens, koji je prvi počeo oglašavati konvikt. Naime, na samoj naslovnici Narodnih novina iz 6. kolovoza 1852. objavljen je »otpis vis. c. k. banske vlade od 15. serpnja o. g. br. 7155 ustanovljena je za one koji bi kao platjajući gojenici u ovdašnji kralj. plemićki konvikt za nastojeću školsku godinu 1852/3 želieli stupiti, godišnja taksa od 160 kruna, kao što je i prošle godine bila. Samo se primjetuje, da ce se u ovaj zavod primat izključivo mladići gimnazie, kao za odgojivanje sposobni« (Clemens, 1862).

Godine 1860. promijenjena je upravna nadležnost konvikta. Državna vlast predala je, tj. vratila isusovcima upravu konvikta i crkve sv. Katarine »tako ipak, da se toli dotični zakladni imutak, kao i naukovni sustav i narodni jezik sačuva čitav i nepovriedjen«. Ta je odluka izazvala nepovoljne reakcije dijela državne uprave, koja je smatrala da će tim potezom biti »nadahnut razvitak slavske narodnosti, ili u opće odgojivanju naše omladine «. Tu je pažnja bila usmjerena na negativne stavove prema isusovcima i na njihova obrazovna i odgojna načela, koje je vlast tom odlukom prihvatila kao pravovaljane (NN, 1860).

U listopadu 1863. obnovljena je zgrada konvikta i ponovno je oglašen u novinama, a u rujnu 1867. mladomisnik Blaž Švinderman bio je imenovan nadstojnikom nauka u konviktu. (NN, 1863). U rujnu 1871. novim ravnateljem imenovan je Miroslav Nagel, koji je do tada obavljao dužnost podravnatelja (NN, 1871). Između 1863. i 1867. vlasti su se ponovno počele miješati u upravu konvikta. Najprije su početkom 1864. povećane plaće zaposlenicima konvikta, da bi odlukom iz 23. srpnja 1866. br. 3043 bilo formirano povjerenstvo za pisanje novih konviktskih pravila, koja su trebala biti "u duhu vremena”. Arhivski izvori kažu da »naročito bje naloženo i naglašeno da se pravila prerade onako, da se organički štatut zavoda razluči od ovih naputaka koji su namjenjeni pojedinim organima zavodske uprave. [...] naputci se čistokrat mijenjanju [...] štatut ne mijenjati puno« (Hervoić, 1874, 8).

Tijekom ožujka 1869. konvikt je posjetio Franjo Josip I. u pratnji hrvatskoga bana Levina Raucha. Bio je to posjet inspiriran proglašenjem Hrvatsko-ugarske nagodbe. Međutim, pravi razlog njegova posjeta konviktu bilo je odlikovanje ta- 
dašnjega ravnatelja Stjepana Vukovića vitezom treće klase Reda željezne krune i podravnatelja Miroslava Nagela vitezom Reda Franje Josipa (Bosanac, 1896, 13-4).

\section{Konvikt i pitomci}

Konvikt su mogli pohađati pitomci katoličke vjeroispovijesti koji su polazili obrazovni program gornjogradske gimnazije. Prema načinu financiranja boravka i rada u konviktu, pitomci su mogli biti stipendisti, koji su primali stipendiju, ili solventi, koji su se sami financirali. ${ }^{3}$

Svi su pitomci bili podijeljeni prema dobi i razredima u tri družbe. Svaka družba imala je posebnu dvoranu za učenje. Pitomci najnižih razreda spavali su u zajedničkoj spavaonici, a ostali (obično počevši od trećega razreda) imali su jednokrevetne sobe. U Državnom arhivu u Zagrebu sačuvan je tlocrt soba drugoga kata. Ukupno ih je 18, a na njemu piše da sobe imaju ukupno 73 kreveta. Veličina je pojedine sobe između 12 i 35 kvadratnih metara. Svaka je družba bila pod nadzorom jednoga nastojnika, koji je bio gimnazijski profesor. Nastojnici ili njihovi zamjenici, koji su pak bili kandidati za buduće učitelje, nadzirali su učenje i pratili napredak pitomaca. Oni su, između ostaloga, sastavljali izvješća o boljitcima pitomaca koja su svaki mjesec bila slana roditeljima ili skrbnicima pitomaca.

Pitomci konvikta razlikovali su se u odjeći od ostalih učenika. Od 1830., kada je konviktom upravljao Ignjat Kristijanović, započela su službena uniformiranja pitomaca tako da su nosili crvenu kapu te tamno plavi kaput i hlače. Međutim, pitomcima se nije svidjelo nošenje crvene kape zbog koje su ih ismijavala druga djeca na zagrebačkim ulicama. Opisi u arhivskim izvorima idu do te razine da su pitomce zbog crvenih kapa navodno znali napadati bikovi i volovi. Međutim, isti ne bilježe konačan ishod te situacije. (Bosanac, 1896, 12-3). Od 1894. njihova je odjeća bila istovjetna onoj kakva se nosila u vojnim školama (Vrkljan, 1996, 134).

3 HR-DAZG-235. Plemićki konvikt u Zagrebu. 1883./1941. 3. Predmetni spisi, 1909./1940., br. 15.930-1909 \& br. 11267. 
Tablica 1. Odjeća pitomaca i cijene odjeće

Table 1. Boarding school students' clothing and its cost

\begin{tabular}{|c|c|c|}
\hline Pitomci & Naziv odjevnoga predmeta & $\begin{array}{l}\text { Cijena (u } \\
\text { krunama) }\end{array}$ \\
\hline \multirow{8}{*}{ Stipendisti } & Paradna bluza & \multirow{7}{*}{50} \\
\hline & Paradne hlače & \\
\hline & Zimsko domaće odijelo & \\
\hline & Ljetno domaće odijelo & \\
\hline & Ovratnik & \\
\hline & Kapa & \\
\hline & Par rukavica & \\
\hline & UKUPNO & 50 \\
\hline \multirow{14}{*}{ Solventi } & Kabanica & 50 \\
\hline & Paradna bluza & 40 \\
\hline & Paradne hlače & 18 \\
\hline & Zimsko domaće odijelo (od lodena) & 30 \\
\hline & Hlaće od lodena & 11 \\
\hline & Ljetna bluza od lodena & 14 \\
\hline & Ljetne hlače od lodena & 10 \\
\hline & Kapa & 4,50 \\
\hline & Ovratnik & 2,20 \\
\hline & Male rukavice (par) & 1,70 \\
\hline & Velike rukavice (par) & 1,90 \\
\hline & Mač & 16 \\
\hline & Remen za mač & 3 \\
\hline & UKUPNO & 202,30 \\
\hline \multirow{7}{*}{$\begin{array}{l}\text { Stipendisti i } \\
\text { solventi }\end{array}$} & Godišnji najam mača i remena & 10 \\
\hline & Godišnja naknada za popravke odjeće & 10 \\
\hline & Godišnja naknada za čišćenje obuće & 12 \\
\hline & Šišanje & 2 \\
\hline & Čišćenje odijela & 2 \\
\hline & Polugodišnja naknada za pranje rublja & 15 \\
\hline & UKUPNO & 51 \\
\hline
\end{tabular}




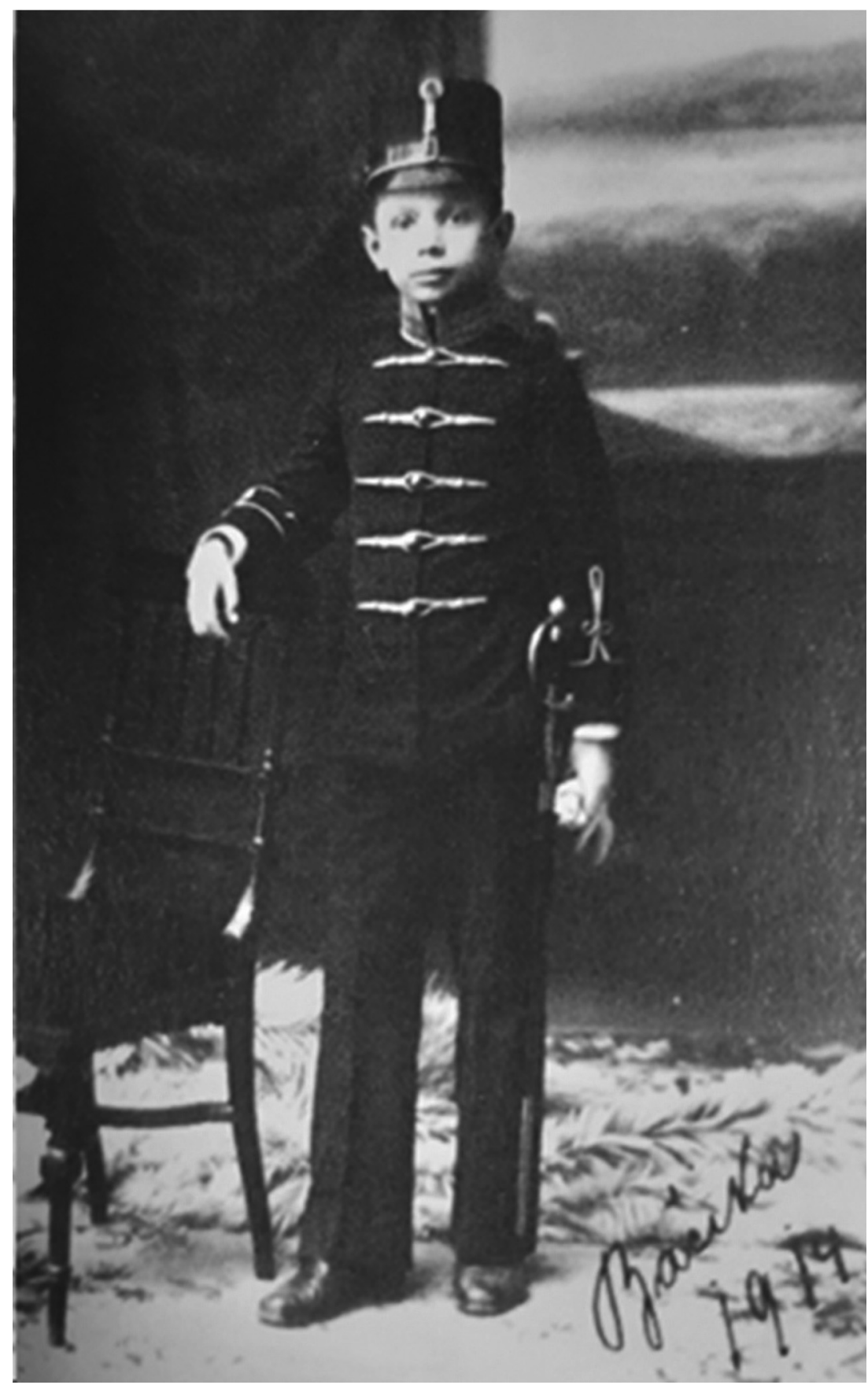

Slika 1. Jedna od rijetkih fotografija pitomca u službenoj odjeći. Zvonimir Vrkljan fotografiran 1914. godine (Vrkljan, 1996, 134).

Figure 1. A rare photo of a boarding school student in formal uniform. Zvonimir Vrkljan photographed in 1914 (Vrkljan 1996, p. 134). 


\subsection{Briga o novcu pitomaca}

Temeljem paragrafa 28 konviktskoga statuta »ne smije ni jedan pitomac donje gimnazije imati kod sebe novaca«. Zato su roditelji ili skrbnici nešto novca za manje potrebe (poput kupovine papira, olovaka, užine i sl.) ostavljali kod konviktskoga ekonoma, koji je novac davao pitomcu »kad ustreba« i na koncu polugodišta o tom je morao »polagati račun « roditeljima. Pitomci su potpisivali tzv. namire, kojima su dokazivali za što su točno tražili novac, iznos i koliko ga planiraju potrošiti. Taj je dokument ovjeravalo ravnateljstvo konvikta i čak je bilo bilježeno državnim biljegom od 14 filira. Analizom arhivskih izvora zaključujemo da su pitomci najčešće dobivali 40 kruna po namiri. ${ }^{4}$

\subsection{Odgoj i obrazovanje pitomaca}

Uz obvezne predmete, koji su bili nauk vjere, hrvatski jezik, njemački jezik, zemljopis, povijest, matematika, mjerstvo i mjerstveno risanje, opisno mjerstvo, prirodopis, fizika, kemija, filozofijska propedeutika, prostoručno risanje, krasnopis te gimnastika, pitomci su od trećega razreda mogli učiti engleski, francuski i talijanski jezik te izučavati stenografiju potpuno besplatno. Ako su željeli učiti neki drugi strani jezik, to su mogli činiti uz dopuštenje ravnateljstva i na vlastiti trošak. Arhivski izvori, pak, pokazuju da to uopće nije bio slučaj. Poseban učitelj u konviktu, koji je bio »carski i kraljevski časnik u pričuvi«, pitomce je vježbao »vojničke kretnje«, a time brinuo i za njihov tjelesni odgoj. Uz to, za pitomce viših razreda bila je obvezna »obuka u plesu i salonskom vladanju«, za što su pitomci morali platiti 10 kruna. Za glazbeni odgoj bio je zadužen konviktski »učitelj pjevanja i tamburanja«, a pohađanje toga bilo je dobrovoljno. ${ }^{5}$

\subsection{Neprimjereno ponašanje i kažnjavanje pitomaca}

Analizom arhivskih izvora dnevničkih bilješki, koje su zabilježili profesori, ujedno i odgojitelji u konviktu u razdoblju između šk. god. 1895./1896. i 1913./1914., autori navode sljedeće "nestašluke” pitomaca: opći nemar, nemar u učenju, učestale tučnjave među pitomcima, svojevoljno ponašanje i odlazak ranije na spavanje od predviđenoga vremena, pljuvanje, pušenje i laganje pred prefektom, krađa, neovlašteno šetanje, lijenost, otpornost i zaboravljanje prefektovih naredbi, fućkanje i zaostajanje za drugima u šetnji, smijanje, nabacivanje papirom, neznanje, loše vladanje, prijevara da pitomac ide zubaru, gledanje kroz prozor tijekom nastave, ćuškanje, brbljanje, kriomice čitanje nedopuštenih knjiga tijekom nastave, razgovor tijekom nastave, dobacivanje narančama, odgovaranje starijim osobama, nedolazak na sat, nemar u učenju, nedolazak ravnatelju (prefektu) zbog izazivanja tučnjave, opetovani nemar, rastezanje među pitomcima za

4 HR-DAZG-235. Plemićki konvikt u Zagrebu. 1883./1941. 3. Predmetni spisi, 1909./1940., Naputak roditeljima ili skrbnicima, koji šalju pitomce u kr. plemićki konvikat zagrebački, str. 1-3.

5 HR-DAZG-235. Plemićki konvikt u Zagrebu. 1883./1941. Dokumentacija o radu ustanove, Predmetni spisi, Dokumentacija o pitomcima, sign. br. 403-4, 7, 428, 429, 430, 430a. 
uši, nemarnost u odijevanju, loš napredak u mjesecu, pod satom je više pitomaca odjednom bilo u zahodu, nepristojno ponašanje tijekom molitve, zlobno zadirkivanje jedan drugoga, nepristojno vladanje pod molitvom, ćuškanje plemića među pitomcima, drsko ponašanje, halabučenje, nevršenje kućnoga reda, indolencija, jedenje ukradenih kompota iz smočnice, preskakivanje u susjedovo dvorište, prkosno vladanje, oduzimanje jela međusobno među pitomcima, igranje nogometa bez dopuštenja, surovost, razuzdano vladanje, divljačko natjerivanje i veranje kroz zahodski prozor, ljenčarenje u krevetu, klizanje po hodnicima i zahodu, izgovaranje laži da za ručak jedu konjsko meso u konviktu i da im je to dao za jelo prefekt, ostavljanje kape cijelu noć na kiši, natjerivanje po hodnicima, jezičavost, izgovaranje prostota, neurednost, divlje naguravanje sa stolcima po komardi, vikanje na korektura, penjanje na vrh peći i sjedenje na njoj, bacanje gaća u zahod nakon čega se zahod zaštopao, vješanje na zvono i zvonjenje, pisanje svinjarija na papirić, zalijevanje hodnika vodom, pušenje u vrtu pored profesora, prkos, pucanje u kokoši pri čemu je jedna ubijena, ranjavanje mačem, oštećivanje zidova, ulijevanje vode u jelo, varanje profesora osam dana da je kabanica na popravku, namjerno prljanje uniforme, nered u ladici, izrugivanje, razbijanja bočica o telegrafski stup, razbijanje lampe na Cmroku, nepristojno sekiranje profesora, tuča među pitomcima s noževima te krađa dvadeset staklenki pekmeza iz smočnice. ${ }^{6}$

U izvorima, uz profesorske bilješke o neprimjerenim ponašanjima, nalazimo i zapisane predviđene kazne, jer je svako pojedinačno ili grupno neprimjereno ponašanje bilo i sankcionirano. Kazne su najčešće bile izricane u obliku oduzimanja jela (ponekad i do pet obroka), šibanja ruku, stajanja u mjestu, zatvora u sobi pitomca (ponekad i deset sati), premještanje u drugi razred (»kako bi se smirila pitomčeva uzavrela krv«), razgovor s ravnateljem konvikta, te kao krajnja mjera isključenje iz konvikta, tj. otpuštanje. ${ }^{7}$ Kazne su u konviktu prvenstveno služile kao mjerilo discipliniranja, a na temelju arhivskih izvora može se zaključiti da su one češće bile represivne nego permisivne prirode. Takav tip kazne prisutan je učestalo kroz povijest odgoja, gdje je osnovna represivna mjera bila tjelesna kazna ili oduzimanje jela s ciljem postizanja discipline i pokornosti autoritetu.

Naime, zbog navikavanja učenika na pokornost, škola je tijekom 19. stoljeća bila organizirana kao kazneni mikro-sustav unutar kojega su rabljena razna “odgojna” sredstva (Župan, 2008), najčešće represivna. Svrha represivnih mjera bila je da učenici nastavno gradivo pamte brže i sigurnije. U školama je vladala pretjerana strogost, a batina je bila čudotvorno sredstvo protiv svakoga zla, neznanja i lijenosti, ili je služila kao sredstvo pokretanja morala (Tauš i Munjiza, 2006, 69). Bol je trebala u djetetu pobuditi unutrašnju motivaciju da se popravi jer je u kontekstu toga vremena predstavljala nenadoknadivo odgojno sredstvo (Borojević, 1901, 435-438). Odgoj na takav način prezentira upute razvoju mo-

6 HR-DAZG-235. Plemićki konvikt u Zagrebu. Knjiga dnevničkih bilješki od šk. god. 1895./1896. do 1913./1914.

7 HR-DAZG-235. Plemićki konvikt u Zagrebu. Knjiga dnevničkih bilješki od šk. god. 1895./1896. do 1913./1914. 
ralnih osjećaja, ali i raspoloženja koja su bila smatrana osnovama moralnoga habitusa. Odgoj je bio usmjeren idejom čovjeka koja je označavala da se biološki zadani pojedinac razvija u moralnu i pedagoški zadanu osobnost. Odgajanje je tako, u biti svoje namjene, služilo kao vrijednosno usmjeravanje, obogaćivanje, izgrađivanje i oplemenjivanje čovjeka. Njegovu bitnost predstavlja vrijednosno doživljavanje, nastojanje oko prenošenja, rasađivanja i očitovanja vrijednosti buđenjem vrijednosnih doživljaja (Vuk-Pavlović, 1932).

Isto tako, treba naznačiti da su ideja čovjeka i potrebe društva dva moguća ishodišta i cilja odgoja — humanističkoga i funkcionalističkoga, ali i da proizlaze iz različitih polazišnih osnova. Humanistički se izražava kao sloboda i samostalnost s gledišta cilja, osobnost i kreativnost s gledišta doprinosa inovativnosti te humanost uvažavanja razvojnih mogućnosti s obzirom na dob i socijalne okolnosti (Komar, 2007, 296). Drugi se izražava kao nastavak pragmatične koncepcije koja je polazila od krajnje svrhe, produkta i učinka, koji je odgovarao društvenim uvjetima i zahtjevima toga vremena (Previšić, 2005, 168).

Razdoblje koje istražujemo u ovom radu obilježeno je uvelike na općoj odgojno-obrazovnoj razini i Školskim zakonom donesenim 1874., u kojem se, među ostalim, nalazi i odredba da vjerske škole postaju javne, ali i važan zaokret prema dokidanju tjelesnoga kažnjavanja (Rosandić, 2013). Tadašnje su školske vlasti odlučile ukinuti tjelesnu kaznu, što je i bilo u skladu s liberalnim nastojanjem Mažuranićeve reforme školstva. Prije donošenja takve odluke, u hrvatskim se školskim časopisima aktivno raspravljalo o uporabi tjelesne kazne. Primjerice, tomu se intenzivno protivio Stjepan Basariček, a za njezino potpuno izbacivanje bio je Skender Fabković (Fabković, 1872). Odjel za bogoštovlje i nastavu za pučke je škole 1876. zabranio uporabu tjelesne kazne, ali nakon niza pritužbi učitelja izdao je 1879. novu naredbu (br. 817) kojom je tjelesna kazna ponovno dopuštena prema strogo propisanim uvjetima te se dopušta isključivo u slučaju većih moralnih prijestupa, kao i zbog tvrdokornoga laganja, drzovite upornosti, prostačina i krupnih nećudorednosti, kao i tada kada sva sredstva discipliniranja ostaju neuspješna (NN, 1884, 129-130).

Iz navedenoga zaključujemo da represivni postupci u konviktu koji su vidljivi iz arhivskoga gradiva nisu izlazili izvan okvira svojega vremena te je način izricanja kazne na kraju 19. stoljeća na općoj školskoj sceni poprilično sličan. No, ono što je svakako zanimljivo činjenica je da su učenički nestašluci i neprimjerena ponašanja i danas ostali gotovo identični, što u konačnici potvrđuje stvarnu prirodu djeteta. Taj zaključak ne korespondira s današnjim prisutnim shvaćanjem u pedagogiji koja ide u smjeru da ne postoji opća ili univerzalna priroda djeteta iz koje je moguće očitati što je djetetu, tj. učeniku potrebno za zdrav razvoj ili što su dječje razvojne potrebe. Priroda djeteta u našem kontekstu mnogo više oslikava ono što jedno društvo smatra važnim. Ta očekivanja, i prikrivena i objavljena, nisu kolektivno obvezujuća i nisu jedinstveno provediva (Bašić, 2011, 31), što iz ranije navedenoga nije slučaj i krajem 19. stoljeća. 


\subsection{Odmor i zabava pitomaca}

Usprkos strogim pravilima, pitomci su imali zaista veliki izbor sadržaja za odmor i zabavu. Postojale su dvije zabavnice, dva dvorišta i posebno »igralište za LawnTennis«, kuglanu te sprave za različite igre kao »Croquet, Hockey, Nogomet, Boccia itd.«Svakoga praznika pitomci su morali ići dva puta na kraće i dulje šetnje u pratnji jednoga nastojnika, a inače po jedanput na dan. Na pismeni ili usmeni poziv roditelja, skrbnika ili znanca, pitomac je mogao s dopuštenjem ravnateljstva konvikta »na proste dane i blagdane pohoditi roditelje i znance te i objedovati kod njih«. Za blagdane Božića, Uskrsa i Duhova pitomci su bili puštani na zahtjev roditelja ili skrbnika i izvan Zagreba. Uz tjelesni odmor, »za duševni odmor i šire obrazovanje imadu pitomci knjižnicu od neko 3000 svezaka«. Stariji su pitomci mogli uz dopuštenje ravnateljstva i u pratnji nastojnika ići u kino, kazalište, slušati predavanja ili koncerte. ${ }^{8}$

Od 1892. do 1913. konvikt je izdavao beletristički list Domovina, u kojem su pisali pitomci. Izlazio je u sklopu čitateljskoga društva osnovanoga 1842., čiji je cilj bio »društveni napredak i društveni odgoj pitomaca« (Vrkljan, 1996, 134). Na kraju, društvo je toliko napredovalo da su unutar konvikta uspjeli osnovati knjižnicu koja je brojila oko 1.550 svezaka (Bosanac, 1896, 16).

\section{Pitomac i konvikt u kontekstu pedagogijske misli na prijelazu stoljeća}

Arhivski izvori koje su autori analizirali potvrđuju u pedagoškom smislu da se odgoj i obrazovanje pitomaca odvija u duhu izvorne isusovačke odgojno-obrazovne orijentacije. Cura personalis ("briga o pojedincu") glavna je značajka isusovačkoga odgoja i obrazovanja, koji prepoznaje razvojne faze intelektualnoga, afektivnoga i duhovnoga rasta, pomažući svakomu učeniku da postupno sazrijeva. Isusovačko odgojno-obrazovno usmjerenje stavlja težište na razvoj osobnosti i volje, nadilaženja sebičnosti i razvoja brige za druge, koja razvija pravični sustav discipline. Jednako je važna i samodisciplina svakoga pojedinoga učenika, koja se očituje u intelektualnoj čvrstoći, upornoj primjeni ozbiljnoga učenja te u ophođenju prema drugima koje iskazuje priznanje ljudskomu dostojanstvu svakoga pojedinca. U isusovačkom odgoju i obrazovanju kriterij izvrsnosti primijenjen je na sva područja školskoga života (Barkan, 1990, 74). U isto vrijeme, na općoj pedagoškoj sceni vlada orijentacija da se djetinjstvo veže uz »zaštićeni prostor « (Bašić, 2011) ili uz »pedagoški moratorium« (Zinnecker, 1996; Honig, 2008), pod kojim podrazumijevamo vremensko razdoblje u kojem su djeca (učenici) izdvojeni iz neposrednoga sudjelovanja u životu odraslih i od zarađivanja za život kako bi vrijeme provodili u učenju i odgoju. Za to vrijeme učenici žive u pedagoškim ustanovama, gdje im odgajatelji i učitelji kao predstavnici društvenih normi i kulture posreduju skrb putem odgoja i nastave (Bašić, 2011), koja se odnosi na njihov mentalni, tjelesni i duhovni napredak. To je u konačnici vidljivo i iz predgovora knjige Uzgojna skrb za zaštitu i spašavanje djece i mladeži od moralnog 
brodoloma, u kojoj se odgoj i obrazovanje predstavljaju kao briga za unaprjeđenje zdravstvenoga, intelektualnoga i ćudorednoga boljitka svakoga pojedinca, dok god on ne postane sposoban za samostalnu privredu, čime prestaje daljnja potreba skrbi za njega (Tomašić, 1911, 1). Pedagoški moratorij u 19. stoljeću odredile su dvije oprečne slike, a to su prosvjetiteljska i romantična slika djeteta. U prosvjetiteljskoj perspektivi dijete nije razumni (umni) i odgovorni pojedinac, ali je obdaren razumskim sposobnostima i zato je u odgoju riječ o kultiviranju, discipliniranju i moraliziranju njegovih nagona te o izgradnji sustavno uređene predodžbe svijeta, nazora o svijetu i životu putem nastave i odgoja. Pedagoški odnos podrazumijeva neupitnu nadmoć odgajatelja, koji odgovorno mora zahvaćati u svijet učenika. Dijete je do reformsko-pedagoškoga pokreta početkom 20. stoljeća shvaćenoga kao adresat odgojnoga djelovanja kompetentnih odraslih, a odgajateljeva je zadaća poticati pozitivne i suzbijati negativno opažene osobine, modele ponašanja, vrijednosti i dr. (Bašić, 2011). Život pitomaca odražava djelomično i prosvjetiteljsku sliku djeteta, što je korespondentno s prosvjetiteljskom pedagogijom (1850.-1918.), unutar koje su se izmijenile tri različite tendencije na domaćoj sceni: 1. teologijska usmjerenost i nadahnuća u pedagogiji od sredine 70-ih godina 19. stoljeća, karakteristična upravo za konvikt; 2. herbartistički pristup od sredine 70-ih godina 19. stoljeća; 3. jačanje reformskih pravaca u pedagogiji uz postupno slabljenje herbartizma od početka 20. stoljeća do Prvoga svjetskoga rata (Radeka, 2010).

Početak sustavnoga razvoja teorije odgoja u Hrvatskoj u prva dva desetljeća prve etape snažno je zakriljen teologijskom dominacijom njezinih glavnih predstavnika Stjepana Ilijaševića, Stjepana Novotnyja i Martina Štiglića. Kao vodeći profesori pedagogije i savjetnici u prosvjetnoj službi uočili su nedostatak pedagogijske literature na hrvatskom jeziku. Stoga u duhu teologizirane pedagogije pišu udžbenike i priručnike za pedagogijsko i didaktičko-metodičko osposobljavanje školskih nadzornika i učitelja u učiteljskim školama. To razdoblje završava 70-ih godina 19. stoljeća započetom sekularizacijom školstva, koja je pokrenuta Zakonom o pučkim školama i preparandijama donesenim 1874. (Radeka, 2010, 117), što se je, naravno, ponajviše odrazilo i na rad samoga konvikta, koji je djelovao za vrijeme sustavnih promjena.

\section{Konvikt i 1914. godina}

Početkom 20. stoljeća Zemaljska vlada odlučila je izraditi novu zgradu konvikta te iz njega stvoriti elitni odgojni zavod po uzoru na bečki i peštanski na zagrebačkoj Šalati. Tada je to bio uglavnom nenaseljeni dio Zagreba koji je obilovao kaptolskim i nadbiskupskim vinogradima. Pitomci su u novoj zgradi imali na raspolaganju kupalište s bazenom u suterenu te veliku biblioteku i čitaonicu u potkrovlju zgrade (Vrkljan, 1996, 135-137).

Prvi svjetski rat, koji je započeo sredinom 1914., ostavio je posljedice i na rad konvikta. Posljednju školsku godinu prije početka rata u konviktu je bilo čak 80 pitomaca. Kao tijekom 19. stoljeća, vojska je uselila u zgradu, ali ovoga puta u svrhu konačenja. Pokretnine konvikta završile su u Medicinskom fakultetu. Dio 
je kupio Klub medicinara zagrebačkoga sveučilišta za svoju menzu, a pokućstvo i rublje pripalo je znanstveno-istraživačkim institutima Medicinskoga fakulteta. Čitava biblioteka poklonjena je Nacionalnoj i sveučilišnoj biblioteci u Zagrebu. U zgradu u Habdelićevoj ulici kasnije je useljen Statistički ured, a u zgradu u Vitezovićevoj ulici došao je Turistički klub činovnika (Cuculić, 1918, 1-3).

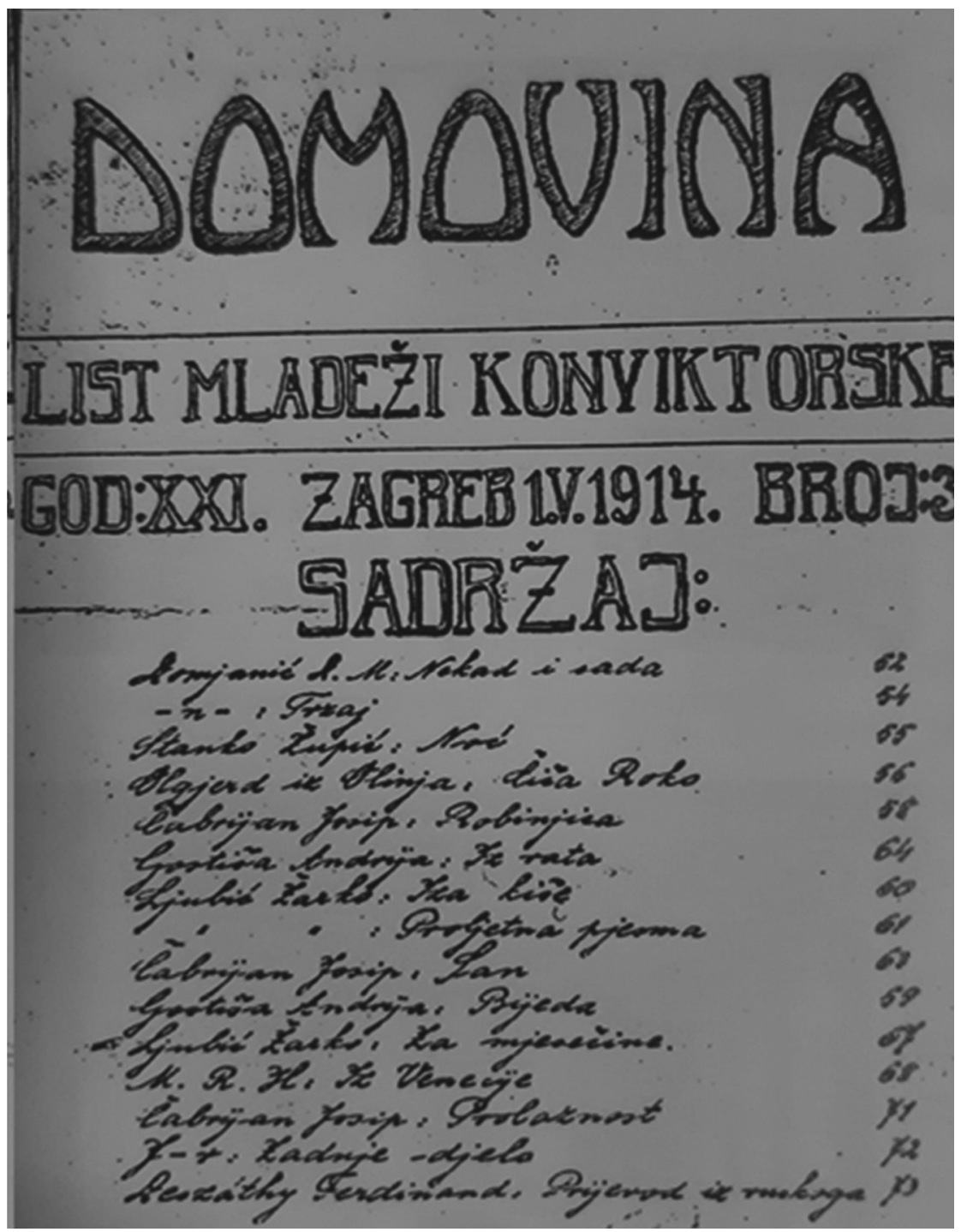

Slika 2. Posljednji primjerak časopisa Domovina. Na naslovnoj stranici nalazi se pjesma Dragutina Domjanića Nekad i sada, u kojoj uspoređuje staru i novu zgradu konvikta.

Figure 2. The last copy of the journal Domovina. The title page contains a poem by Dragutin Domjanić, Then and Now (Nekad i sad), in which he compares the old and new buildings of the boarding school. 


\section{Zaključak}

Plemićki konvikt u Zagrebu bio je ključna zagrebačka odgojno-obrazovna institucija mladih tijekom druge polovice 19. stoljeća. Iako je bio izvorno zamišljen za odgoj i obrazovanje siromašne djece, s vremenom je postao dostupan svim slojevima zagrebačkoga društva. To je najbolji dokaz koliko je društvo poštovalo djelatnost konvikta, pa im nije bilo problem izdvajati dio novčanih sredstava za kvalitetan odgoj i obrazovanje svoje djece. Važno je naglasiti da je osnutak konvikta bio podržan kako državnom vlašću, tako i lokalnom. Lokalno plemstvo to čini na način da od svojih financijskih i materijalnih viškova osniva zaklade za financiranje siromašnijih učenika. Društvu su mladi, odgojeni i obrazovani pojedinci bili prijeko potrebni, a sva je pažnja u formiranju takve djece bila usmjerena prema konviktu. On je radio i djelovao sukladno političkim i povijesnim mijenama na hrvatskom prostoru. U slučaju ratne ili političke krize nije djelovao, ali te okolnosti nisu ga zaustavile u daljnjem djelovanju. Osim toga, nastojanje državnih vlasti da imaju sve veći utjecaj u upravnom i organizacijskom radu konvikta u duhu sveopće sekularizacije odgoja i obrazovanja nisu uspjele jer je svaka izmjena rezultirala lošim ishodima. Stoga, način rada i djelovanja konvikta s opće-odgojnim i teologijskim usmjerenjima ostao je kvalitativna odgojna konstanta sve do početka Prvoga svjetskoga rata. U konviktu je vladao strogi odgojni sustav prema učenicima, koji im je mogao omogućiti dobru pripremu za samostalan život, opće-kulturno ponašanje, ali i zapaženu ulogu u društvu. Zanimljivo je uočiti kako se osim naglašavanja etičkih i moralnih vrijednosti u konviktu njegovala i financijska pismenost, kako bi učenici kasnije mogli pravilno raditi s novcem. Svako neprimjereno ponašanje učenika bilo je kažnjavano u duhu tadašnjih odgojnih pravila. Tu valja naglasiti da je upravo u vrijeme druge polovice 19. stoljeća aktualna problematika reformne pedagogije, koja je nastojala što više ublažiti tradicionalne tjelesne kazne, koje je nastojala zamijeniti radnim ili psihički motiviranim kažnjavanjem. Cjelokupna odgojno-obrazovna djelatnost konvikta nimalo ne odstupa od ustaljenih pedagogijskih normi, ali istovremeno djeluje u duhu novih pedagogijskih tendencija. Uz to, po prvi puta se u arhivskim izvorima takve vrste spominje dokolica i slobodno vrijeme kao uobičajeni dio učenikova dnevnoga ritma, za koju se konvikt pobrinuo na način da su nastojali organizirati veliku ponudu odmora i zabave za pitomce. Upravo taj postupak isključuje bilo kakvu primisao na društvenu izolaciju pitomaca. Samokritički možemo zaključiti da su teologizirane pedagogijske tendencije u konviktu bile stup odgojno-obrazovnoga uspjeha tadašnjega vremena, iz kojih je moguće separirati vrijednosti koje bi vrijedile i u današnjem društvu.

\section{Literatura}

Barkan, M. Steven (1990). Jesuit legal education: Focusing the vision. Marquette Law Review, 1,74 .

Bašić, Slavica (2011). (Nova) slika djeteta u pedagogiji djetinjstva. U: Dubravka Maleš (ur.), Nove paradigme ranog odgoja (str. 19-37). Zagreb: Filozofski fakultet Sveučilišta u Zagrebu. 
Borojević, Miloš (1901). Tjelesna kazna. Napredak, 27, str. 435-438, 451-453, 486-489, 502-504, 564-565, 623-625, 679-691.

Bosanac, Stjepan (1896). Kralj. plemićki konvikat u Zagrebu: 1796-1896. Zagreb: Knjigotiskara i litografija C. Albrecht.

Clemens, Josip (1862). Hervatska, Slavonia, Dalmacia i vojvodia Sebia. Narodne novine, 18(179), 1.

Fabković, Skender (1872). Treba li dokinuti tjelesnu kaznu? Napredak, 13, 97-100; 24, $185-6 ; 32,504-512$.

Honig, Michael-Sebastian (2008). Work and care: Reconstructing childhood through childcare policy in Germany. U: Allison James i Adrian L. James (ur.), European Childhoods: Cultures, Politics and Childhoods in Europe (str. 198-215). London: Palgrave Macmillan.

Komar, Zvonimir (2007). Pedagogija: Između ideje čovjeka i potreba društva: Nabačaj problema i temeljna izlazišta. U: Vlatko Previšić et al. (ur.), Pedagogija prema cjeloživotnom obrazovanju i društvu znanja: Sv. 2 (str. 269-304). Zagreb: Hrvatsko pedagogijsko društvo.

Laszowski, Emilij (1939). Prinosi za povijest sjemeništa (konvikta) sv. Josipa u Zagrebu (1653-1752). Vrela i prinosi, 9, 61-110.

NN (1860). Dopisi, Austrijanska carevina. Narodne novine, 190, 1-2

NN (1863). Dopisi Narodnim novinam. Narodne novine, 234, 2.

NN (1871). Trojedna kraljevina, Zagreb, 11. rujna. Obzor, 34, 3.

NN (1884). Naredbe izdane na osnovu školskog zakona od 14. listopada 1874. do konca godine 1882. Zagreb: Naklada Hrvatsko-slavonsko-dalmatinske zemaljske vlade.

Previšić, Vlatko (2005). Kurikulum suvremenog odgoja i škole: metodologija i struktura. Pedagogijska istraživanja, 2(2), 165-173.

Radeka, Igor (2010). Pedagogija i ideologija u Hrvatskoj. U: Drago Roksandić i Ivana Cvijović Javorina (ur), Zbornik radova Desničini susreti 2010 (str. 111-136). Zagreb: Filozofski fakultet u Zagrebu.

Rosandić, Josip (2013). Razvoj školstva u Hrvatskoj od 60-ih godina 19. stoljeća do kraja 20. stoljeća (Doktorski rad). Filozofski fakultet Sveučilišta Josipa Jurja Strossmayera u Osijeku.

Tauš, Josipa; Munjiza, Emerik (2006). Represivne i permisivne mjere u odgoju djece mlađe školske dobi. Život i škola, 52(15-16), 69-78.

Tomašić, Ivan (1911). Uzgojna skrb za zaštitu i spašavanje djece i mladeži od moralnog brodoloma. Zagreb: Tiskara Weiser.

Vanino, Miroslav (1969). Isusovci i hrvatski narod I. Zagreb: Filozofsko-teološki institut Družbe Isusove.

Vrbanus, Milan (s. a.). Učitelji i profesori u Hrvatskoj i Slavoniji. U: Od protomodernizacije do modernizacije školstva u Hrvatskoj. URL: http://histedu.isp.hr/excel-baze-podataka/ (27.03.2019.)

Vrkljan, Zvonimir (1996). Plemićki konvikt u Zagrebu. U: Vinko Ivić i Ivan Ružić (ur.), Iz starog i novog Zagreba VII (str. 133-139). Zagreb: Muzej grada Zagreba.

Vuk-Pavlović, Pavao (1932). Ličnost i odgoj. Zagreb: Tipografija D. D.

Zinnecker, Jürgen (1996). Kindheit in Deutschland: Aktueller Survey über Kinder und ihre Eltern (Kindheiten). Juventa: Kindheiten.

Župan, Dinko (2008). Odnos prema tijelu unutar hrvatskog školskog sustava druge polovine 19. st. Radovi Zavoda za hrvatsku povijest Filozofskog fakulteta Sveučilišta u Zagrebu, 40(1), 189-209. 


\title{
Arhivsko gradivo
}

Nacionalna i sveučilišna knjižnica u Zagrebu:

Hervoić, Ljudevit (1874). Povjesnica kr. plem. konvikta. (Rukopis, Zbirke rukopisa i starih knjiga Nacionalne i sveučilišne knjižnice u Zagrebu, R-3029). Zagreb.

Cuculić, Tomo (1937). Opće je bio priznat odgojni rad Kr. plemićkog konvikta u Zagrebu (Rukopis). Zagreb: Nacionalna i sveučilišna knjižnica u Zagrebu.

Hrvatski državni arhiv:

HR-HDA-516. Kraljevski plemićki konvikt.

HR-HDA-516, V-2. Kraljevski plemićki konvikt Zagreb. Vodič.

Državni arhiv u Zagrebu:

HR-DAZG-235. Plemićki konvikt u Zagrebu.

Education at the Jesuit Monastery School Plemićki konvikt in Zagreb from 1852 to 1914

\author{
Katarina Dadic*, Vlatko Smiljanic***
}

\section{Summary}

Based on the analysis and critical interpretation of archival material, newspaper articles and relevant literature, the authors research the internal organization of the Plemićki konvikt boarding school in Zagreb, which was a secondary school. It is at the foundation of the Jesuit educational tradition and a major influence upon historical-political circumstances since its re-establishment in the mid-19th century until WWI 1914-1918. The paper focuses on organizational and educational postulates of the boarding activities as well as on the everyday life of the boarding school students in the said period. It is important to emphasize that the establishment of the boarding school was supported both by state and local governments. The local nobility did so by setting up a fund for financing the poorer students from out of their financial and material surpluses. Society was in need of young, well-reared and educated individuals, such that all attention with regard to the formation of these children was focused on the boarding school. Its mode of operation and functioning with regard to general educational and theological orientation remained a qualitative educational constant until the beginning of WWI. A strict educational system for the pupils was enforced which would prepare them for an independent life, a cultural demeanor and a major role in society. The overall educational activity of the boarding school does not, however, deviate from established pedagogical norms, nevertheless at the same time, acts in the spirit of new pedagogical tendencies.

Key words: boarding school pedagogy; Jesuits; history of education; Plemićki konvikt in Zagreb

* Katarina Dadić, Ph.D., Assistant Professor. Faculty of Croatian Studies, University of Zagreb. Address: Borongajska cesta 83d, 10000 Zagreb, Croatia. E-mail: kdadic@hrstud.hr

** Vlatko Smiljanić, MA of History, Faculty of Croatian Studies, University of Zagreb. Address: Borongajska cesta 83d, 10000 Zagreb, Croatia. E-mail: vsmiljanic@hrstud.hr 